\title{
KONTRIBUSI DUKUNGAN SOSIAL TERHADAP MOTIVASI BERPRESTASI SISWA DI SMP NEGERI BATANG KAPAS
}

\author{
MORI DIANTO \\ STKIP PGRI Sumatera Barat \\ moridianto25@gmail.com
}

\begin{abstract}
This research was done because of phenomenon of the students' low motivation to get the achievement at school. Social support have a correlation for creating the students' potential giftedness to get an achievement in learning. The role of the teachers, especially the teachers of guidance and counseling are needed in improving the students' achievement at school in order to improve their learning achievement. This research has purpose to find the social support and achievement motivation of SMPN Kecamatan Batang Kapas Pesisir Selatan. This research used correlational approach which has purpose to know how is the contribution among the research variables. The population of the research is the students of SMPN Kecamatan Batang Kapas Pesisir Selatan. The amount of the population was 601 students. The sample of this research was 240 students. It had been taken by using simple random sampling technique. The instruments used in the form of scale. The data was analyzed by using descriptive technique and the hypothesis testing was done by using korelasional. The result shows that: (1) social support is in the enough category, (2) students' achievement motivation is in the enough category, (4) the contribution of social support through the students' achievement motivation is about 20.2\%. The above findings imply that social support have contributed to students achievement motivation. Needs to be done similar studies were suggested to conduct at different contexts to compare the findings.
\end{abstract}

Keywords: Social Support, Achievement Motivation

\section{PENDAHULUAN}

Permasalahan yang dialami siswa di sekolah seringkali tidak dapat dihindari seperti permasalahan motivasi berprestasi dalam proses belajar siswa sering tidur, meski dengan pengajaran yang baik sekalipun. Hal ini terlebih lagi disebabkan karena sumber-sumber permasalahan siswa banyak yang terletak di luar sekolah seperti sikap orangtua yang kurang perhatian terhadap anak dan anggota keluarga yang tidak bersahabat, iklim kekerasan dan kurang disiplin yang berlangsung di masyarakat.

Proses belajar siswa di sekolah dipengaruhi oleh beberapa faktor diantaranya motivasi, minat, kebiasaan belajar dan karakter kepribadian. Pernyataan di atas, maka jelaslah bahwa motivasi merupakan suatu faktor yang menyumbang pada prestasi siswa. Selain itu dengan adanya dukungan sosial yang baik pada siswa, maka akan terbentuk konsep diri yang baik dan akan melahirkan motivasi berprestasi yang baik pula, karena motivasi berprestasi akan membentuk siswa dalam meningkatkan atau mempertahankan kecakapan pribadi setinggi mungkin dalam segala aktivitas

Menurut Dianto (2015:20) Motivasi berprestasi mempunyai andil tertentu untuk mewujudkan pendidikan siswa yang lebih optimal dikarenakan siswa yang mempunyai motivasi berprestasi yang tinggi maka prestasi dalam belajarnya akan meningkat. Untuk meningkatkan motivasi berprestasi ada beberapa faktor yang mempengaruhi seseorang tersebut mempunyai motivasi berprestasi menurut 
McClelland (2010:37-38) yang dapat mempengaruhi motivasi berprestasi seseorang, 1) Keluarga. 2) Konsep diri. 3) Jenis kelamin. 4) pengakuan dan prestasi. Motivasi berprestasi seseorang dapat dipengaruhi oleh lingkungan sosial seperti orangtua, guru, teman dan lingkungan masyarakat. Dalam keluarga baik atau buruknya motivasi berprestasi seorang anak tergantung bagaimana cara orangtua mengasuh anak agar mempunyai motivasi berprestasi.

Menurut Nicholls dan Miller (Woolfolk, 1995:103), teori motivasi terutama motivasi berprestasi banyak dikaitkan dengan orientasi tujuan (goal orientation) yaitu apakah siswa akan mengacu pada dirinya sendiri dan lebih berorientasi pada usaha berprestasi itu sendiri (task orientation) atau siswa lebih tertarik pada imbalan-imbalan dari luar dirinya (ego orientation).

Duval dan Miller (1985:70) mengemukakan bahwa dukungan dapat berbentuk seperti mendorong, bekerja sama, menunjukkan persetujuan, cinta, afeksi dan fisik. Sebagai makhluk sosial yang hidup dalam suatu lingkungan sosial, individu selalu membutuhkan individu lain disekitarnya untuk memberikan dukungan atau bantuan bila ia mengalami masalah atau kesusahan. Dukungan sosial secara umum mengacu pada bantuan yang diberikan pada seseorang oleh orang-orang yang berarti baginya seperti keluarga dan teman.

Manusia sebagai makhluk sosial selalu membutuhkan interaksi dengan individu lain dalam kehidupannya. Menurut Brofenbrenner (Santrock, 1995:85) orangtua, guru dan teman merupakan agen sosial yang berada dalam lingkungan mikrosistem individu untuk berinteraksi dalam kehidupan sehari-hari maka keluarga, teman, sekolah dan tetangga. Siswa menghabiskan sebagian besar waktunya untuk berinteraksi dengan lingkungan keluarga dan lingkungan sekolah.

Proses belajar siswa sangat membutuhkan dukungan sosial, seperti dukungan sosial orangtua kepada anaknya dalam proses belajar di rumah, dukungan sosial teman dalam motivasi belajar kelompok dan dukungan sosial guru dalam proses belajar di sekolah. Permasalahan yang timbul dari dukungan sosial dalam meningkatkan motivasi berprestasi siswa yakni orangtua kurang memperhatikan anak dalam belajar, kebutuhan untuk belajar di rumah dan di sekolah. Permasalahan lainnya yaitu dalam belajar kelompok, dalam belajar kelompok terlihat hanya sebagian siswa saja yang aktif dalam belajar kelompok, dalam proses belajar, pembelajaran yang diberikan guru tidak menarik, sehingga mempengaruhi motivasi siswa dalam belajar. Dukungan sosial orangtua dalam memenuhi kebutuhan belajar siswa, seperti kebutuhan buku. Serta kurangnya dukungan sosial guru dalam disiplin belajar siswa, sehingga siswa seringkali keluar masuk dalam proses belajar dan kurangnya pengelolaan kelas sehingga dalam proses belajar kurang efektif, hal lain yang ditemukan yakni siswa seringkali terlambat datang ke sekolah sehingga siswa ketinggalan materi dalam proses belajar dan mengakibatkan motivasi berprestasi siswa kurang

Berdasarkan fenomena yang terjadi pada siswa yang diuraikan di atas, peneliti melihat bahwa kemampuan motivasi berprestasi siswa di sekolah perlu dikaji dan diteliti. Maka penulis tertarik melakukan sebuah penelitian dengan judul "Kontribusi Dukungan Sosial Terhadap Motivasi Berprestasi di Sekolah Menengah Pertama". Adapun tujuan dala penelitian ini untuk dapat melihat langsung dukungan sosial dan motivasi beprestasi siswa di sekolah. 


\section{METODE}

Penelitian ini menggunakan pendekatan korelasional yang bertujuan untuk mengetahui seberapa besar kontribusi antara variabel penelitian. Adapun variabel dalam penelitian ini terdiri dari dukungan sosial (X) sebagai dependent variable dan motivasi berprestasi (Y) sebagai independent variable. Dalam penelitian ini akan dilihat kontribusi dari dependent variable dukungan sosial terhadap independent variable motivasi berprestasi.

Populasi dalam penelitian ini adalah seluruh siswa SMP Negeri Kecamatan Batang Kapas Pesisir Selatan yang aktif Tahun Ajaran 2017/2018. Dalam penelitian ini peneliti mengambil kelas VIII sebagai populasi sedangkan kelas VII dan kelas IX tidak dimasukkan dalam populasi penelitian, karena kelas VII termasuk dalam siswa baru sedangkan kelas IX akan mengikuti ujian nasional. Populasi dalam penelitian ini sebanyak 601 siswa yang tersebar pada 5 sekolah. Teknik pengambilan sampel dalam penelitian ini adalah Proportional random sampling. Sampel dalam penelitian ini sebanyak 240 siswa. Instrumen yang digunakan pada penelitian ini berupa instrumen dukungan sosial dan motivasi berprestasi. Menggunakan model skala Likert. Untuk instrumen penelitian ini sudah divalidasi dari beberapa ahli dan juga uji reliabilitas di lapangan.

Teknik-teknik analisis yang dilakukan adalah dengan mendeskripsikan tingkat dukungan sosial dan motivasi berprestasi dengan menggunakan teknik statistik deskriptif. Statistik deskriptif adalah statistik yang digunakan untuk mendeskripsikan atau menggambarkan data yang telah terkumpul sebagaimana adanya tanpa bermaksud membuat kesimpulan yang berlaku untuk umum atau generalisasi (Sugiyono, 2008:147). Data yang diperoleh dari instrumen akan diolah dengan memberikan skor masing-masing item.

Analisis data yang dilakukan adalah dengan mendeskripsikan dukungan sosial, konsep diri dan motivasi berprestasi siswa dengan menggunakan rumus:

$$
\mathrm{P}=\frac{\mathrm{f}}{n} \times 100
$$

\section{Keterangan :}

$\mathrm{P}=$ Tingkat persentase jawaban

$\mathrm{f}=$ Frekuensi jawaban

$\mathrm{n}=$ Jumlah sampel

Tingkat ketercapaian masing-masing variabel berguna untuk mengambarkan pencapaian responden secara kualitatif pada masing-masing variabel.

Uji persyaratan analisis dilakukan terhadap data penelitian sebagai dasar pertimbangan untuk memilih dan menetapkan jenis teknik analisis data yang akan digunakan dalam pengujian hipotesis penelitian. Uji persyaratan yang dilakukan pada data penelitian meliputi:

\section{a. Pengujian Normalitas}

Pengujian normalitas dilakukan untuk mengetahui normal tidaknya suatu distribusi data (Supardi, 2012:129). Uji normalitas dalam penelitian ini menggunakan bantuan SPSS 20.0 yaitu dengan uji liliefors dengan ketentuan: Jika $\mathrm{L}_{\text {hitung }}$ maksimal kecil dari $\mathrm{L}_{\text {tabel }}$ maka data berdistribusi normal. Jika $\mathrm{L}_{\text {hitung }}$ maksimal besar dari $\mathrm{L}_{\text {tabel }}$ maka data tidak berdistribusi normal. 


\section{b. Uji Homogenitas}

Uji homogenitas untuk memperlihatkan bahwa dua data atau lebih kelompok data sampel berasal dari populasi yang memiliki variansi yang sama. Pada uji homogenitas sama seperti uji kenormalan, uji kehomogenan menghasilkan banyak keluaran. Untuk keperluan penelitian umumnya, hanya perlu keluaran Test of Homogenity of Variance saja. Insterpretasi dilakukan dengan memilih salah satu statistik, yaitu statistik yang didasarkan pada rata-rata (Based on Mean). Varian dinyatakan homogen jika ternyata pengujian statistik based on Mean diperoleh signifikansi $>0,05$

\section{c. Uji Linearitas}

Menurut Supardi (2012:145) persyaratan uji statistik parametrik analisis asosiasi lainnya yang diperlukan adalah uji kelinearan regresi. Pengujian kelinearan regresi dilakukan dalam rangka menguji model persamaan regresi suatu variabel $\mathrm{Y}$ terhadap suatu variabel $\mathrm{X}$. Perhitungan linearitas dalam penelitian ini menggunakan bantuan program SPSS (Statistical Product and Service Solution) for windows release 20.0.

Untuk menafsirkan hasil uji linearitas, kriteria yang digunakan adalah $\mathrm{X}$ dan $\mathrm{Y}$

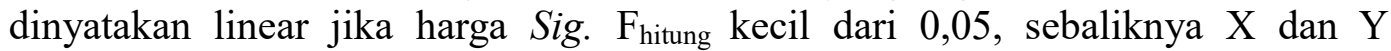
dinyatakan tidak linear jiga harga Sig. $\mathrm{F}_{\text {hitung }}$ besar dari 0,05 .

\section{d. Pengujian Hipotesis Penelitian}

Untuk menguji hipotesis penelitian ini dilakukan langkah-langkah sebagai berikut (Riduwan dan Engkos, 2012:116-118):

a. Merumuskan persamaan struktural

Struktur: $Y=\rho_{\mathrm{YX} 1} X_{1}+\rho_{\mathrm{YX} 2}+\rho_{\mathrm{Y}} \epsilon_{1}$

b. Menghitung koefisien jalur yang didasarkan pada koefisien regresi

Persamaan regresi ganda: $Y=a+b_{1} X_{1}+b_{1} X_{2}+\epsilon_{1}$

c. Menghitung koefisien jalur secara simultan (keseluruhan)

Untuk menghitung koefisien jalur secara simultan (keseluruhan) menggunakan rumus sebagai berikut:

$$
F=\frac{(n-k-1) R^{2} Y X_{K}}{k\left(1-R^{2} Y X_{K}\right)}
$$

keterangan:

$\mathrm{n}=$ jumlah sampel

$\mathrm{k}=$ jumlah variabel eksogen

$\mathrm{R}^{2} \mathrm{YX}_{\mathrm{K}}=\mathrm{R}$ square

Jika $\mathrm{F}_{\text {hitung }} \geq \mathrm{F}_{\text {tabel }}$ maka terdapat pengaruh yang signifikan dengan taraf signifikansi $(\alpha)=0,05$.

\section{HASIL PENELITIAN DAN PEMBAHASAN}

\section{HASIL PENELITIAN}

Data penelitian ini terdiri dari tiga variabel, yaitu data variabel dukungan sosial $\left(\mathrm{X}_{1}\right)$, data variabel konsep diri $\left(\mathrm{X}_{2}\right)$, dan data variabel motivasi berprestasi (Y). Data tersebut dideskripsikan sebagai hal-hal berikut. 


\section{Dukungan sosial orangtua, guru dan teman}

Gambaran distribusi frekuensi skor dukungan sosial skor dukungan sosial berada di atas kelas interval skor rata-rata, 37,08\% skor dukungan sosial di bawah kelas interval skor rata-rata, dan $84,16 \%$ skor dukungan sosial berada di atas kelas interval skor rata-rata. Ini berarti bahwa sebagian besar skor dukungan sosial berada di bawah kelas interval rata-rata. Selanjutnya, hasil analisis tingkat pencapaian siswa untuk setiap sub variabel dukungan sosial dapat dilihat pada

Tabel 1. Deskripsi Rata-Rata (Mean) dan Persentase (\%) Data Dukungan Sosial Berdasarkan Sub Variabel

\begin{tabular}{|r|l|r|r|r|r|r|r|r|c|}
\hline \multirow{2}{*}{ No } & \multicolumn{9}{|c|}{ SKOR } \\
\cline { 2 - 10 } & Sub-Variabel & \multicolumn{1}{|c|}{ Ideal } & Max & \multicolumn{1}{c|}{ Min } & \multicolumn{1}{c|}{$\Sigma$} & Mean & \multicolumn{1}{c|}{ \% } & \multicolumn{1}{c|}{ Sd } & Ket \\
\hline 1 & Dukungan Emosional (9) & 45 & 43 & 14 & 6671 & 27,8 & 61,76 & 3,98 & Kurang \\
\hline 2 & Dukungan Penghargaan (4) & 20 & 20 & 9 & 3949 & 16,5 & 82,27 & 2,38 & Baik \\
\hline 3 & Dukungan Instrumental (3) & 15 & 15 & 6 & 3033 & 12,6 & 84,25 & 1,73 & Baik \\
\hline 4 & Dukungan Informasi (5) & 25 & 25 & 12 & 5036 & 20,98 & 83,93 & 2,55 & Baik \\
\hline 5 & Dukungan Kelompok (9) & 45 & 45 & 27 & 9137 & 38,1 & 84,6 & 3,87 & Baik \\
\hline \multicolumn{2}{|c|}{ Keseluruhan } & 150 & 143 & 85 & 27826 & 115,9 & 77,29 & 9,16 & Cukup \\
\hline
\end{tabular}

\section{Catatan:}

Ket = Keterangan

$\mathrm{Sd} \quad=$ Standard deviasi

Berdasarkan Tabel 1 di atas dapat diketahui bahwa tingkat capaian rata-rata secara umum sebesar 77,29 \%. Ini berarti bahwa menurut siswa secara umum mereka cukup mendapatkan dukungan sosial. Jika dilihat dalam bentuk dukungan emosional dari orangtua, guru dan teman masih kurang, hanya $61,76 \%$. Ini dapat dikatakan siswa belum mendapatkan dukungan emosional yang tinggi dari orangtua, guru dan teman.

\section{Motivasi berprestasi}

Gambaran distribusi frekuensi skor motivasi berprestasi dapat diketahui bahwa $28,33 \%$ dari skor motivasi berprestasi berada pada kelas interval skor rata-rata, $20,83 \%$ skor motivasi berprestasi berada di atas kelas interval skor rata-rata, dan $66,66 \%$ skor motivasi berprestasi berada di bawah kelas interval skor rata-rata. Ini berarti bahwa sebagian besar skor motivasi berprestasi siswa berada di bawah kelas interval rata-rata. Selanjutnya, hasil analisis tingkat capaian responden untuk setiap sub variabel motivasi berprestasi dapat dilihat pada Tabel 2 berikut.

\section{Tabel 2: Deskripsi Rata-Rata (Mean) dan Persentase (\%) Data}

\section{Motivasi Berprestasi Berdasarkan Sub Variabel}

\begin{tabular}{|r|l|r|r|r|r|r|r|r|c|}
\hline \multirow{2}{*}{ No } & \multicolumn{9}{|c|}{ SKOR } \\
\cline { 2 - 11 } & Sub-Variabel & \multicolumn{1}{|c|}{ Ideal } & \multicolumn{1}{c|}{ Max } & \multicolumn{1}{c|}{ Min } & \multicolumn{1}{c|}{$\sum$} & \multicolumn{1}{c|}{ Mean } & \multicolumn{1}{c|}{$\%$} & \multicolumn{1}{c|}{ Sd } & Ket \\
\hline 1 & Resiko pemilihan tugas & 30 & 30 & 16 & 5738 & 23,91 & 79,69 & 2,96 & Baik \\
\hline 2 & Kesempatan untuk unggul & 25 & 25 & 11 & 4673 & 19,5 & 77,88 & 3,45 & Cukup \\
\hline 3 & Membutuhkan umpan balik & 30 & 30 & 7 & 3861 & 16,09 & 80,44 & 2,68 & Baik \\
\hline 4 & Tanggung jawab & 25 & 25 & 13 & 6041 & 25,2 & 71,92 & 4,46 & Cukup \\
\hline 5 & Ketekunan & 25 & 25 & 11 & 4735 & 19,7 & 78,92 & 3,34 & Cukup \\
\hline 6 & Berprestasi & 15 & 15 & 6 & 2410 & 10 & 66,9 & 2,52 & Cukup \\
\hline \multicolumn{2}{|r|}{ Keseluruhan } & 150 & 145 & 81 & 27458 & 114,4 & 76,27 & 13,28 & Cukup \\
\hline
\end{tabular}

\section{Catatan:}

Ket = Keterangan

$\mathrm{Sd} \quad=$ Standard deviasi

Berdasarkan Tabel 2 di atas dapat diketahui bahwa tingkat capaian rata-rata secara umum adalah sebesar 76,27\%. Tingkat capaian ini berada pada kategori cukup. Ini 
berarti motivasi berprestasi siswa dalam hal ini masih tergolong cukup. Jika dilihat berdasarkan sub variabel, terdapat capaian siswa yang paling rendah berada pada sub variabel berprestasi dengan capaian sebesar 66,9\%, dan capaian yang paling tinggi adalah pada kebutuhan untuk mendapatkan umpan balik.

\section{Kontribusi Dukungan Sosial terhadap Motivasi Berprestasi}

Uji data diolah mengunakan SPSS versi 20.0 dapat dilihat pada Tabel 22 Model Summary berikut.

Tabel 22. Model Summary Dukungan Sosial Terhadap Motivasi Berprestasi

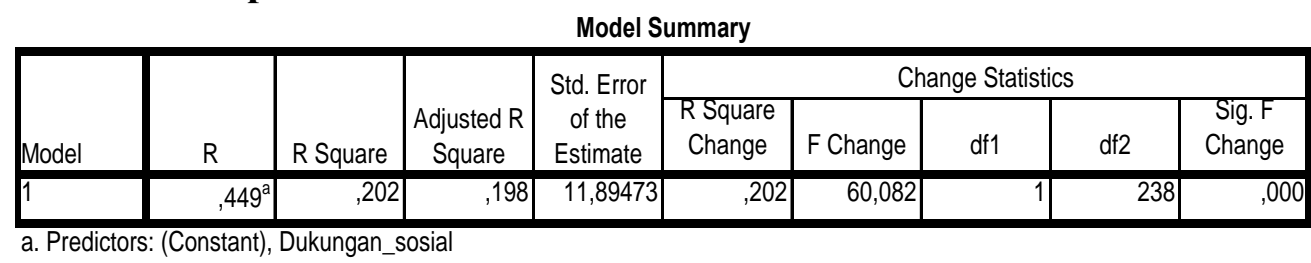

Uji signifikansi dicari yaitu membandingkan antara nilai probabilitas 0,05 dengan nilai probabilitas Sig. Dasar pengambilan keputusan sebagai berikut.

1) Jika nilai probalitas 0,05 lebih kecil atau sama dengan nilai probalitas $\mathrm{Sig}$ atau $(0,05 \leq \mathrm{Sig})$, maka Ho diterima dan Ha ditolak, artinya tidak signifikan.

2) Jika nilai probalitas 0,05 lebih besar atau sama dengan nilai probalitas Sig atau $(0,05 \geq S i g)$, maka Ho ditolak dan Ha diterima, artinya signifikan.

Terlihat bahwa pada kolom Sig (signifikan) pada Tabel 22 Model Summary, didapat nilai Sig 0,000. Kemudian nilai Sig 0,000 lebih kecil dari nilai probabilitas 0,05 atau nilai $0,05>0,000$, maka Ho ditolak dan Ha diterima artinya koefisien adalah signifikan. Jadi, dukungan sosial berkontribusi secara signifikan terhadap motivasi berprestasi.

\section{PEMBAHASAN}

\section{Dukungan Sosial}

Hasil penelitian menunjukkan bahwa tingkat capaian rata-rata dukungan sosial secara umum adalah sebesar 77,29\% dari skor ideal. Tingkat capaian ini berada pada kategori cukup. Ini berarti bahwa secara umum dapat dikatakan siswa mempunyai dukungan sosial yang termasuk kategori cukup. Dukungan sosial yang termasuk pada tingkat capaian cukup ini perlu ditingkatkan lagi dengan melaksanakan pelayanan bimbingan dan konseling, adapun layanan yang akan dilakukan yakni layanan informasi, layanan konseling individual, konseling kelompok, bimbingan kelompok, dan pelayanan lainnya yang menyangkut permasalahan yang dialami siswa.

Menurut Smith (Prayitno dan Amti, 2004:94) bimbingan sebagai proses layanan yang diberikan kepada individu-individu guna membantu mereka memperoleh pengetahuan dan keterampilan-keterampilan yang diperlukan dalam membuat pilihan-pilihan, rencana-rencana, dan interpretasi-interpretasi yang diperlukan untuk menyesuaikan diri yang baik. Karena dengan memberikan pelayanan bimbingan konseling yang baik tentang dukungan sosial, maka kemampuan siswa dalam melakukan aktivitas di sekolah, masyarakat dan bergaul dengan teman sebaya akan meningkat dengan baik. 
Watkins dan Baldo (Anggraeni, 2009:95) berpendapat bahwa dukungan sosial adalah perasaan positif, menyukai, kepercayaan, dan perhatian dari orang lain yaitu orang yang berarti dalam kehidupan individu yang bersangkutan, pengakuan, kepercayaan seseorang dan bantuan langsung dalam bentuk tertentu. Selain mengadakan kontak-kontak sosial manusia juga membutuhkan dukungan dari orang lain dalam mengantisipasi dan menghadapi suatu masalah. Dukungan sosial juga dapat dilihat dari banyaknya kontak sosial yang terjadi atau yang dilakukan individu dalam menjalin hubungan dengan sumber-sumber yang ada di lingkungan. Penelitian ini lebih menekankan pada dukungan sosial yang bersumber dari teman, keluarga, dan guru. Sarafino (2011:81) menyatakan empat aspek dukungan sosial yaitu, dukungan emosional, penghargaan, instrumental, dan informatif.

Dukungan sosial berasal dari orang-orang penting yang dekat bagi individu yang membutuhkan bantuan misalnya di sekolah seperti guru dan temantemannya. Penulis menekankan pada dukungan sosial keluarga yang akan mempengaruhi self regulated learning anak dalam proses belajar mereka.

Selanjutnya, jika dilihat berdasarkan sub variabel, terdapat tingkat capaian responden yang paling rendah berada pada sub variabel dukungan sosial dalam dukungan emosional dengan tingkat capaian sebesar $61,77 \%$ dari skor ideal. Ini berarti dukungan sosial masih kurang dalam bentuk emosional. Dukungan emosional yang diterima individu dari orang-orang disekitarnya dalam bentuk kasih sayang, penghargaan, perasaan didengarkan, perhatian dan kepercayaan yang diperoleh individu dalam memecahkan masalah yang dihadapinya, baik masalah pribadi atau masalah yang berkaitan dengan studi, dengan adanya pelayanan bimbingan dan konseling maka dukungan emosional siswa terhadap orang lain bisa lebih baik lagi.

Fischer (Tarmidi, 2010:217) juga menyatakan bahwa salah satu hal yang berperan penting di dalam pembentukan kemandirian belajar pada diri siswa adalah dari dukungan yang diterima oleh siswa dari komunitas tempat siswa berada, seperti dari sekolah, teman, orangtua, guru, dan sebagainya. Siswa yang memiliki dukungan sosial yang lebih kecil, lebih memungkinkan mengalami kelemahan dari berbagai hal. Seperti lemahnya pergaulan siswa, kurangnya kemampuan siswa dalam berinteraksi dan siswa mengalami konsekuensi psikis yang negatif.

Keuntungan siswa yang memperoleh dukungan sosial yang tinggi akan menjadi individu lebih optimis dalam menghadapi kehidupan saat ini maupun masa yang akan datang, lebih terampil dalam memenuhi kebutuhan psikologi dan memiliki sistem yang lebih tinggi, serta tingkat kecemasan yang lebih rendah, mempertinggi interpersonal skill (keterampilan interpersonal), memiliki kemampuan untuk mencapai apa yang diinginkan dan lebih dapat membimbing individu untuk beradaptasi dengan baik.

Berdasarkan penjelasan di atas dapat dipahami bahwa kiranya perlu adanya suatu upaya untuk melaksanakan bimbingan dan konseling khusus materi dukungan sosial, dalam hal ini dukungan sosial orangtua, guru dan teman yang diperoleh siswa tidak maksimal, orangtua yang tidak peduli terhadap pendidikan siswa, sehingga dukungan sosial yang di dapatkan siswa tidak maksimal. Misalnya memberikan materi dalam bentuk layanan informasi, adapun materi 
yang dapat dilakukan adalah meningkatkan hubungan dengan orangtua, guru dan teman.

\section{Gambaran Motivasi Berprestasi Siswa}

Berdasarkan hasil penelitian menunjukkan bahwa tingkat capaian rata-rata secara umum motivasi berprestasi siswa adalah sebesar 76,27\% dari skor ideal. Tingkat capaian ini berada pada kategori cukup. Ini berarti motivasi berprestasi siswa tergolong cukup. Motivasi berprestasi yang termasuk pada tingkat capaian cukup ini perlu ditingkatkan, adapun untuk meningkatkan motivasi berprestasi siswa di sekolah maka peran guru bimbingan dan konseling sanagat di butuhkan sekali, seperti memberikan layana informasi dimana informasi yang diberikan adalah informasi yang bisa meningkatkan motivasi berprestasi siswa, hal lainnya yakni memberikan layanan bimbingan kelompok, layanan konseling kelompok serta memberikan konseling individual kepada siswa yang membutuhkan lebih jauh lagi tentang motivasi berprestasinya di sekolah.

Menurut Hamzah (2012:1) Motivasi adalah dorongan dasar yang menggerakkan seseorang bertingkahlaku. Motivasi lebih dekat pada mau melaksanakan tugas untuk mencapai tujuan dan juga motivasi adalah kekuatan, baik dari dalam maupun dari luar yang mendorong seseorang untuk mencapai tujuan tertentu yang telah ditetapkan sebelumnya.

Seseorang melakukan sesuatu atau bertingkahlaku dalam belajar karena adanya yang mendorong menggerakkannya untuk melakukannya, sedangkan motivasi berprestasi dalam siswa adalah kekuatan yang menggerakkan siswa, mengarahkannya, mengatur dan menentukan apa yang akan atau tidak akan dilakukan dalam upaya mencapai prestasi belajar yang telah ditetapkan.

McClelland (2010:43) menyatakan bahwa: achievement motivation increases in all types of subjects thoughts of doing well with respect to some standard of good performance, of being blocked in the attempt to achieve, of trying various means of achieving, and of reacting with joy or sadness to the results of one's efforts.

Berdasarkan pendapat ini memberikan pemahaman bahwa motivasi berprestasi adalah sama-sama mendorong meningkat disemua jenis mata pelajaran, memiikirkan segala sesuatu dengan baik apa yang ingin dilakukan sehubungan dengan beberapa standar kinerja yang telah ditetapkan, upaya untuk mencapai standar, mencoba berbagai sarana untuk mencapai standar, dan bereaksi dengan sukacita atau kesedihan dengan hasil upaya sendiri.

Selanjutnya, jika dilihat berdasarkan sub variabel, terdapat capaian responden yang paling rendah berada pada sub variabel berprestasi dengan capaian sebesar $66,9 \%$ dari skor ideal. Hal ini berarti siswa dalam berprestasi berasa pada kategori cukup tinggi, sehingga terlihat siswa untuk meningkatkan motivasi berprestasinya masih rendah.

Menurut McClelland dkk (Yusuf, 2002:54) dalam temuan penelitian menyatakan bahwa tiap individu mempunyai kebutuhan berprestasi (need for achievement) dalam dirinya yang besar dalam satu rentang dua kecenderungan yang berlawanan, yaitu kecenderungan untuk meraih sukses/berhasil (need for success) dan kecenderungan untuk menghindari kegagalan (need for avoidance).

Dalam pendapat di atas menjelaskan bahawa motivasi untuk berprestasi merupakan sebuah kebutuhan seseorang. Semua orang berkeinginan untuk 
mencapai sebuah kesukses baik dalam berteman maupun dalam kesusksesan dalam prestasi belajar di dunia pendidikan yang muaranya sukses dalam kehidupan masa depan yang cerah.

Seseorang dalam berprestasi ada sebenarnya yang melatarbelakangi menurut McClelland (2010:39) bahwa prestasi seseorang sebenarnya dikendalikan oleh banyak faktor bukan saja untuk memenuhi kebutuhan makan tetapi seseorang berprestasi juga untuk mendapatkan persetujuan sosial, kekuasaan, atau pengetahuan juga tidak kalapentingnya faktor kemampuan.

Adanya dorongan yang membuat seseorang harus berbuat, ini merupakan makna yang terkandung dari penjelasan di atas. Dalam motivasi berprestasi ini ada karakteristik seperti apa seseorang yang mempunyai motivasi berprestasi. Menurut McClelland (2010:43) salah satu ciri mereka yang memiliki motivasi prestasi tinggi adalah menetapkan standar prestasi untuk diri mereka sendiri, dari pada mengandalkan insentif ekstrinsik yang disediakan oleh situasi yang ada di lingkungannya, dan mereka harus berusaha lebih keras dan lebih berhasil untuk mencapai standar yang mereka telah tetapkan untuk diri mereka sendiri.

Berdasarkan penjelasan di atas dapat dipahami bahwa banyak hal yang mendorong seseorang untuk terus berprestasi. Maka dalam memahami sebuah kejadian ada yang melatarbelakangi seseorang berprestasi ini juga perlu didalami agar apa yang ingin dicapai itu bisa dimotivasi lagi agar tambah bersemangat untuk mencapai target yang sudah dibuat itu dan untuk yang mempunyai motivasi yang sangat rendah perlunya meningkatkannya.

Maka guru bimbingan dan konseling haruslah bisa memahami semua siswa bimbingan melalui program yang sudah direncanakan. Karena berdasarkan hasil penelitian siswa menunjuk bahwa tingkat motivasi berprestasi siswa tidak telalu rendah dan tidak tinggi. Dalam posisi yang seperti ini kemungkinan untuk turun mempunyai peluang. Maka perlunya peningkatan motivasi siswa untuk berprestasi dengan cara membuat target kedepan yang akan dicapai. Adapun peran bimbingan dan konseling dalam meningkatkan motivasi berprestasi yakni dengan cara memberikan layanan informasi, adapun materi yang diberikan cara meningkatkan motivasi berprestasi datang ke sekolah tepat waktu, meningkatkan di siplin belajar serta meningkatkan kemampuan dalam proses belajar, layanan yang terkait dengan materi tersebut bimbingan kelompok dengan materi meningkatkan motivasi berprestassi dan layanan konseling individual kepada siswa motivasi berprestasi yang lemah.

\section{Dukungan Sosial Berkontribusi Terhadap Motivasi Berprestasi}

Berdasarkan uji hipotesis pada pembahasan sebelumnya, dapat diketahui bahwa dukungan sosial berkontribusi terhadap motivasi berprestasi dengan koefisien sebesar 20,2\%. Dengan demikian dapat diketahui bahwa dukungan sosial dapat menjelaskan kontribusi motivasi berprestasi sebesar 20,2\%. Ini menjelaskan bahwasanya dukungan sosial berkontribusi terhadap motivasi berprestasi.

Walgito (2002:17) menyatakan bahwa dukungan sosial merupakan hubungan antara individu dengan lingkungannya terutama lingkungan sosial yang bersifat timbal balik, lingkungan mempengaruhi individu dan individu mempengaruhi perkembangan lingkungan. Selain mengadakan kontak-kontak sosial manusia juga membutuhkan dukungan dari orang lain dalam mengantisipasi dan menghadapi suatu masalah. 
McClelland (2010:39) menyatakan bahwa prestasi seseorang sebenarnya dikendalikan oleh banyak faktor bukan saja untuk memenuhi kebutuhan makan tetapi seseorang berprestasi juga untuk mendapatkan persetujuan sosial, kekuasaan, atau pengetahuan juga tidak kalapentingnya faktor kemampuan.

Penelitian tentang motivasi berprestasi dilakukan oleh Dini (2006), dan ditemukan bahwa salah satu hal yang dapat mempengaruhi pembentukan motivasi berprestasi adalah lingkungan sosial. Siswa yang mendapat dukungan dan diberikan kesempatan untuk mengembangkan diri di lingkungan sosialnya akan mempunyai motivasi yang lebih tinggi. Lingkungan sosial remaja yang dimaksudkan dalam penelitian adalah teman sebaya. Berdasarkan wawancara yang dilakukan kepada delapan siswa-siswi SMA Negeri 1 Kajen, didapatkan gambaran bahwa para siswa merasa tertantang untuk mendapatkan prestasi dan berusaha semakin giat belajar, semakin giat mencari informasi dan pengetahuan dari berbagai sumber baik dari perpustakaan maupun dari internet. Disisi lain para siswa juga merasa memiliki kekurangan di dalam menggapai prestasi salah satunya adalah kesulitan belajar sendiri di rumah karena orangtua yang kurang mengerti kondisi siswa. Sejalan dengan hasil wawancara yang dilakukan kepada siswa siswi, hasil wawancara kepada tiga orangtua siswa juga didapat gambaran bahwa orangtua mengharapkan anaknya agar dapat mengukir prestasi setinggitingginya akan tetapi orangtua juga kurang memberikan kebebasan kepada anak untuk dapat belajar bersama dengan teman-teman karena menghawatirkan anaknya akan terjerumus pada pergaulan yang salah. Yusuf (2002:38-39) menyebutkan bahwa salah satu fungsi keluarga adalah pemberi bimbingan dalam belajar dan stimulator bagi pengembangan kemampuan untuk mencapai prestasi, baik di sekolah maupun di masyarakat. Peran keluarga sangat penting terutama di dalam usaha meraih prestasi. Dukungan yang dibutuhkan dapat berupa dukungan emosional, dukungan penghargaan, dukungan instrumental, dukungan informasi, dukungan kelompok. Apabila seorang anak mendapatkan dukungan yang baik dari orangtua maka anak akan lebih termotivasi lagi dalam meraih prestasi.

Dukungan sosial yang diperoleh dari guru, orangtua, dan teman mempengaruhi motivasi berprestasi siswa dalam belajar semakin tinggi dukungan sosial yang diberikan maka meningkatkan motivasi siswa dalam belajar. Agar prestasi seseorang meningkat hal ini diperlukan peran bimbingan dan konseling, di sekolah peran guru bimbingan dan konseling sangat dibutuhkan untuk meningkatkan dukungan sosial dan motivasi berprestasi siswa di sekolah, upaya yang akan dilakukan oleh guru bimbingan dan konseling yakni dengan memberikan materi tentang peningkatan dukungan sosial dan motivasi berprestasi. Seperti memberikan informasi disiplin belajar, mengembangkan motivasi agar berprestasi dalam belajar.

\section{SIMPULAN}

Berdasarkan hasil temuan yang diperoleh dalam penelitian ini, setelah dilakukan analisis statistik dan uji hipotesis serta dikaji dan dijabarkan dalam pembahasan, maka dapat disimpulkan sebagai berikut.

1. Secara umum tingkat pencapaian dukungan sosial di SMP Negeri Kecamatan Batang Kapas Pesisir Selatan berada pada kategori cukup.

2. Secara umum tingkat pencapaian motivasi berprestasi di SMP Negeri Kecamatan Batang Kapas Pesisir Selatan berada pada kategori cukup.. 
3. Dukungan sosial berkontribusi terhadap motivasi berprestasi di SMP Negeri Kecamatan Batang Kapas Pesisir Selatan. Dapat disimpulkan bahwa semakin tinggi dukungan sosial yang diberikan oleh orangtua, guru dan teman maka akan meningkat pula motivasi berprestasi siswa.

\section{REFERENSI}

Dianto, M., Gustiatuti, N., \& Mudjiran. (2015). Kontribusi Dukungan Sosial dan Konsep Diri terhadap Motivasi Berprestasi pada Siswa SMP N Batang Kapas Pesisir Selatan, 4(March), 19-25.

Dinie Ratri D. 2006. "Motivasi Berprestasi Ditinjau dari Dukungan Sosial dan Tingkat Pendidikan Orangtua Pada Siswa RSBI SMA Negeri Kajen Kabupaten Pekalongan”. Jurnal. Semarang: Universitas Diponegoro.

Duval, E.M \& Miller, B.C. 1985. Barriage and Family Development (6 $6^{\text {th }}$ ed). New York: Harper \& Row Publisher Inc.

Hamzah B Uno. 2012. Teori Motivasi \& Pengukurannya. Jakarta: Bumi Aksara.

McClelland, C David. 2010. The Achieving Society. New York: Martini Publishing.

Riduwan dan Engokos Ahmad Kuncoro. 2012. Cara Menggunakan dan Memaknai Path Analisis (Analisis Jalur). Bandung: Alpabeta.

Santrock, J.W. 1995. Life-Span Development jilid 1. Penerjemah: Juda Damanik. Jakarta: Erlangga.

Tarmidi, 2010." Korelasi antara Dukungan Sosial Orangtua dan Self - Directed Learning pada Siswa SMA", Fakultas Psikologi Universitas Sumatera Utara, Jurnal Psikologi, Vol 37, NO. 2: 216 - 223

Walgito, Bimo. 2002. Pengantar Psikologi Umum. Yogyakarta: Andi Offset.

Wolfolk, A.E. 1995. Educational Psychology $\left(6^{\text {th }}\right.$ ed). USA: Allyn and Bacon.

Yusuf, A. Muri. 2002. Kiat Sukses dalam Karier. Padang: Ghalia Indonesia.

Sarafino, E.P. 2011. Health Psychology: Biopsychosocial Interactions 7th. New York: John Wiley \& Sons, Inc.

Prayitno dan Erman Amti. 2004. Dasar-dasar Bimbingan dan Konseling. Jakarta: Gramedia.

Sugiyono. 2008. Metode Penelitian Pendidikan: Pendekatan Kuantitatif, Kualitatif dan $R \& D$. Bandung: Alfabeta.

Supardi. 2012. Aplikasi Statistik dalam Penelitian. Jakarta: Ufuk Press. 
Mekar Dwi Anggraeni, 2009, “Dukungan Sosial yang Diterima oleh Perempuan yang Belum Berhasil dalam Pengobatan Infertilitas", Jurusan Keperawatan Universitas Jenderal Soedirman Purwokerto, Jurnal Keperawatan, Volume 4, No.3 